\title{
Foliar application of kaolin reduces the incidence of sunburn in 'Thompson Seedless' grapevine
}

\author{
A. Hosseinabad and A. Khadivi \\ Department of Horticultural Sciences, Faculty of Agriculture and Natural Resources, Arak University, Arak, \\ Iran
}

\section{Summary}

Grapes are one of the world's largest fruit crops and are widely cultivated in Iran. Sunburn is one of the major problems involved in the cultivation and exploitation of this fruit crop, which leads to a decrease in the apparent quality of the fruit and a sharp drop in marketability, reduced yields, and problems with its export. Therefore, to provide solutions to reduce these problems, the present study was conducted with foliar application of kaolin in four concentrations $(0.00,2.50,5.00$, and $7.50 \%)$ for two times including mid-June and mid-July, on 'Thompson Seedless' grapevine cultivar. The results showed that the sunburn on the berries and leaves was lower in the treated vines than untreated vines, and the best result was achieved with kaolin used in mid-June, which could completely control leaf sunburn. The result also showed that kaolin had a positive effect on bunch length, bunch weight, bunch density, berry length and berry width. Therefore, it is suggested that foliar application of kaolin is a suitable, affordable and inexpensive solution to reduce the damages caused by sunburn in leaves and fruits, especially in areas where the intensity of the sun is high. Due to the fact that there were no sunburns in leaves treated by kaolin in mid-June, it is recommended that the solution may be applied in mid-June.

Keywords

berry quality, grapes, kaolin, sunburn, yield

\section{Introduction}

Grapevine (Vitis vinifera L.) belongs to Vitaceae family and is one of the largest fruit crops in the world (Ruel and Walker, 2006). It is a deciduous plant and has expanded in the world. Its cultivars can produce such high value processed products such as juice, jellies, table grapes, and dietary supplements (Zhang et al., 2009). The rare European-Middle Asian wild grapevine ( $V$. vinifera subsp. sylvestris), is believed to be the living ancestor of modern grapevine cultivars (This et al., 2006).

Grapes are cultivated as an important fruit crop for use in more than 90 countries (Keller, 2010). According to the Food and Agriculture Organization, Iran is the ninth-largest grape producer in the world (FAO, 2014). The main regions producing grape in Iran are located in six provinces including Khorasan, Fars, Qazvin, Zanjan, Azerbaijan-e-Gharbi, and Azerbaijan-e-Shaghi.

Sunburn is a condition that is caused by direct exposure

\section{Significance of this study}

What is already known on this subject?

- Grapes are cultivated as an important fruit crop for use in more than 90 countries. Sunburn is a condition that is caused by direct exposure to sunlight; the skin of the grape is discolored. Sunburn area is a suitable place to grow corrosive microorganisms. Sunburn is caused by high heat and rays of the sun, especially ultraviolet, which cause to change the color of the berry skin to the brown.

\section{What are the new findings?}

- There were no sunburns in leaves and berries treated by kaolin in mid-June, so it is recommended that this solution may be applied in mid-June.

\section{What is the expected impact on horticulture?}

- Foliar application of kaolin is a suitable, affordable and inexpensive solution to reduce the damages caused by sunburn in leaves and fruits, especially in areas where the intensity of the sun is high.

to sunlight; the skin of the grape is discolored. Sunburn area is a suitable place for micro-organisms to attack. Sunburn is caused by high heat and direct sunlight, especially ultraviolet (Glenn et al., 2002), which causes to change the color of the fruit skin to brown (Schrader et al., 2008). In order to reduce injuries caused by sunburn and severe heat, the leaf cover of the plant should maintain by plant nutrition, pest and disease control and suitable pruning to prevent direct contact with sunlight. The appropriate irrigation and fertilization reduce sunburn by contributing to vegetative growth and protecting fruits by the leaves (Glenn et al., 2002). Also, in cases of severe heat stress after a cool period, the plantation should be irrigated if water is available. Shading the fruits with coatings such as paper envelopes or the use of light-reflecting materials such as kaolin can be effective to reduce sunburn of fruits (Melgarejo et al., 2003).

The particle coating technology was introduced in 1999 (Glenn et al., 1999). Particle coating is done with refined white kaolinite that has hydrophilic properties. The suspension of this substance is water that after exposure to air, evaporation and white kaolin with high porosity remain as a protector on the surface of leaves and fruits (Saour, 2005).

Kaolin has unique properties, such that these particles are chemically inert, their particle diameter is less than 2.00 micrometers, formulated with high dispersion and can provide uniformity (Glenn, 2005). The coating produced by this substance is permeable and it does not cause a disturbance 
in the gas exchange of the leaves (Glenn, 2005). It does not block photosynthetic active radiation, but to some extent, it prevents the passage of infrared and ultraviolet rays (Glenn, 2005). Kaolin causes behavioral changes in insects and pathogens and is easily washed out of products (Glenn, 2005). Kaolin increases the reflection of radiation reaching the leaf surface, thereby reducing the heat load of the trees (Glenn and Puterka, 2001).

It has been reported that application of kaolin in olive tree (Olea europaea) caused a significant increase in fruit dry matter that kaolin particle coating treatment in semi-wet Mediterranean regions had a positive effect on olive trees yield; spray was done after fruiting. The increase in the yield of each tree was due to the increase in the weight and size of the fruits (Saour and Makee, 2003). In addition, kaolin significantly increased the final formation of fruit, the number of fruits, and fruit weight in orange fruit (Citrus reticulata) and greatly influenced the decrease in fruit loss (Saleh and El-Ashry, 2006). Furthermore, Imperial apples (Malus domestica 'Empire') fruits have also been improved by application of kaolin (Glenn and Puterka, 2001; Glenn et al., 2003). Increasing the formation of fruit by application of kaolin can be due to insect control or reduction of heat stress and the increase of pure photosynthesis (Attra, 2002).

One of the problems of viticulture in Iran is sunburn, which leads to a decrease in the quality of the grape berries and a sharp decline in marketability, reduced yield and also problems with its export. Thus, the aim of the present work was to evaluate the effectiveness of kaolin for preventing sunburn damage on 'Thompson Seedless' grapevine grown in Ammanabad village in Arak region, Iran.

\section{Materials and methods}

The present research was carried out in a vineyard in Ammanabad village in Arak, Iran, on 20-year-old grape vines 'Thompson Seedless'. Ammanabad is located near Arak region with a height of $1,725 \mathrm{~m}$ a.s.l. The vines were grown under homogeneous conditions in a loamy clay soil. The annual mean temperature in 2016 was $13.70^{\circ} \mathrm{C}$, with mild winters $\left(-2.60^{\circ} \mathrm{C}\right.$ in January) and hot summers $\left(27^{\circ} \mathrm{C}\right.$ in August $)$. An annual precipitation of $320 \mathrm{~mm}$ was recorded, mostly falling in winter and autumn.

'Thompson Seedless' is cultivated to produce table grapes and raisins. Soil analysis was carried out to determine the values of mineral elements and soil non-uniformity analysis. The vines were pruned in such a way that eight buds were kept on each branch and the number of remaining buds on each plant was equal.

The distance between the grape vines was $2.50 \mathrm{~m}$ in rows and $4.00 \mathrm{~m}$ between rows. Furrow irrigation was done every 12 days and was discarded two weeks before the harvest. Pest and disease control, as well as weed removal, were applied equally to all of the vines.

The experiment was carried out in three replications in a factorial arrangement based on randomized complete block design at two times (mid-June and mid-July), in which the effect of various treatments of kaolin $(0.00,2.50,5.00$, and $7.50 \%$ ) was studied for reducing sunburn on berries and leaves of grape 'Thompson Seedless'. Kaolin spraying was carried out on vines, so that all the branches and leaves, and in general, the whole volume of the vines were covered by the solution. The control vines were also sprayed by water. After kaolin spraying, there was no the rainfall during the growing season.

Furthermore, ten bunches per vine in each replicate were randomly taken from each of the four sides of the plant at harvest time. In total, 50 leaves were also harvested randomly from each vine to study leaf color and sunburn effects. Then, several traits including leaf sunburn content, berry sunburn content, bunch length, bunch width, bunch weight, bunch density, number of berries per bunch, berry length, berry width, berry weight, berry color, berry shape, total soluble solids (TSS) of berry and leaf color were measured.

Bunch length, bunch width, berry width, and berry length were measured using a digital caliper. Bunch weight and berry weight were measured using a digital scale. The TSS was measured using a refractometer. Qualitative traits including leaf sunburn, berry sunburn, bunch density, berry color, berry shape, and leaf color were measured based on rating, scoring, and coding according to the grape descriptor (IPGRI, 1997).

The data were grouped, and the average values were used for statistical analysis. Analysis of variance was conducted using the SAS (SAS Institute, Cary, NC), and means were compared by Duncan's new multiple range test at 0.05 .

\section{Results}

\section{Kaolin application in mid-June}

The analysis of variance showed that kaolin application in mid-June had significant effects on bunch density, bunch length, berry length, berry width, berry color, berry

TABLE 1. The effect of kaolin on the qualitative and quantitative characteristics of 'Thompson Seedless' grape in mid-June.

\begin{tabular}{lccccccc}
\hline Treatment & $\begin{array}{c}\text { Berry width } \\
(\mathrm{mm})\end{array}$ & $\begin{array}{c}\text { Berry length } \\
(\mathrm{mm})\end{array}$ & $\begin{array}{c}\text { Number of } \\
\text { berries }\end{array}$ & $\begin{array}{c}\text { Bunch } \\
\text { density }\end{array}$ & $\begin{array}{c}\text { Bunch weight } \\
(\mathrm{g})\end{array}$ & $\begin{array}{c}\text { Bunch width } \\
(\mathrm{mm})\end{array}$ & $\begin{array}{c}\text { Bunch length } \\
(\mathrm{mm})\end{array}$ \\
\hline Control $(0.00 \%)$ & $11.86 \mathrm{~b}$ & $13.40 \mathrm{ab}$ & $132.80 \mathrm{a}$ & $3.40 \mathrm{~b}$ & $171.29 \mathrm{a}$ & $52.33 \mathrm{a}$ & $227.27 \mathrm{~b}$ \\
Kaolin $2.50 \%$ & $12.10 \mathrm{~b}$ & $13.24 \mathrm{~b}$ & $137.37 \mathrm{a}$ & $3.93 \mathrm{ab}$ & $176.20 \mathrm{a}$ & $50.33 \mathrm{a}$ & $245.20 \mathrm{ab}$ \\
Kaolin $5.00 \%$ & $12.34 \mathrm{ab}$ & $13.99 \mathrm{a}$ & $147.80 \mathrm{a}$ & $4.33 \mathrm{a}$ & $178.99 \mathrm{a}$ & $51.80 \mathrm{a}$ & $247.00 \mathrm{ab}$ \\
Kaolin $7.50 \%$ & $12.48 \mathrm{a}$ & $13.59 \mathrm{ab}$ & $134.93 \mathrm{a}$ & $4.20 \mathrm{a}$ & $173.52 \mathrm{a}$ & $49.62 \mathrm{a}$ & $266.93 \mathrm{a}$ \\
\hline \multirow{2}{*}{ Treatment } & Leaf & Leaf & Berry & TSS & Berry & Berry & Berry weight \\
& color & sunburn & sunburn & $(\%)$ & color & shape & $(\mathrm{g})$ \\
\hline Control $(0.00 \%)$ & $1.00 \mathrm{c}$ & $2.33 \mathrm{~b}$ & $2.33 \mathrm{~b}$ & $23.54 \mathrm{a}$ & $1.53 \mathrm{c}$ & $1.80 \mathrm{~b}$ & $1.30 \mathrm{a}$ \\
Kaolin $2.50 \%$ & $3.00 \mathrm{~b}$ & $0.00 \mathrm{a}$ & $0.067 \mathrm{a}$ & $24.93 \mathrm{a}$ & $1.80 \mathrm{bc}$ & $1.00 \mathrm{c}$ & $1.40 \mathrm{a}$ \\
Kaolin $5.00 \%$ & $3.00 \mathrm{~b}$ & $0.00 \mathrm{a}$ & $0.00 \mathrm{a}$ & $23.73 \mathrm{a}$ & $2.73 \mathrm{a}$ & $2.60 \mathrm{~b}$ & $1.45 \mathrm{a}$ \\
Kaolin $7.50 \%$ & $4.33 \mathrm{a}$ & $0.00 \mathrm{a}$ & $0.00 \mathrm{a}$ & $23.53 \mathrm{a}$ & $2.33 \mathrm{ab}$ & $1.13 \mathrm{c}$ & $1.41 \mathrm{a}$ \\
\hline
\end{tabular}

Means followed by the same letters are not significantly different at 0.05 probability using Duncan's test. 
TABLE 2. The effect of kaolin on the qualitative and quantitative characteristics of 'Thompson Seedless' grape in mid-July.

\begin{tabular}{lccccccc}
\hline Treatment & $\begin{array}{c}\text { Berry width } \\
(\mathrm{mm})\end{array}$ & $\begin{array}{c}\text { Berry length } \\
(\mathrm{mm})\end{array}$ & $\begin{array}{c}\text { Number of } \\
\text { berries }\end{array}$ & $\begin{array}{c}\text { Bunch } \\
\text { density }\end{array}$ & $\begin{array}{c}\text { Bunch weight } \\
(\mathrm{g})\end{array}$ & $\begin{array}{c}\text { Bunch width } \\
(\mathrm{mm})\end{array}$ & $\begin{array}{c}\text { Bunch length } \\
(\mathrm{mm})\end{array}$ \\
\hline Control $(0.00 \%)$ & $12.29 \mathrm{a}$ & $13.42 \mathrm{a}$ & $132.93 \mathrm{a}$ & $3.93 \mathrm{a}$ & $161.52 \mathrm{~b}$ & $52.66 \mathrm{a}$ & $253.13 \mathrm{a}$ \\
Kaolin $2.50 \%$ & $12.18 \mathrm{a}$ & $13.45 \mathrm{a}$ & $159.87 \mathrm{a}$ & $4.47 \mathrm{a}$ & $199.95 \mathrm{ab}$ & $58.55 \mathrm{a}$ & $260.20 \mathrm{a}$ \\
Kaolin $5.00 \%$ & $12.03 \mathrm{a}$ & $13.31 \mathrm{a}$ & $140.80 \mathrm{a}$ & $4.20 \mathrm{a}$ & $182.72 \mathrm{ab}$ & $55.85 \mathrm{a}$ & $243.93 \mathrm{a}$ \\
Kaolin $7.50 \%$ & $12.51 \mathrm{a}$ & $13.51 \mathrm{a}$ & $163.33 \mathrm{a}$ & $4.47 \mathrm{a}$ & $220.94 \mathrm{a}$ & $50.91 \mathrm{a}$ & $265.67 \mathrm{a}$ \\
\hline \multirow{2}{*}{ Treatment } & Leaf & Leaf & Berry & TSS & Berry & Berry & Berry weight \\
& color & sunburn & sunburn & $(\%)$ & color & shape & $(\mathrm{g})$ \\
\hline Control $(0.00 \%)$ & $1.00 \mathrm{~b}$ & $3.00 \mathrm{~b}$ & $1.33 \mathrm{~b}$ & $25.41 \mathrm{a}$ & $1.40 \mathrm{a}$ & $1.27 \mathrm{a}$ & $1.39 \mathrm{a}$ \\
Kaolin $2.50 \%$ & $3.00 \mathrm{a}$ & $0.00 \mathrm{a}$ & $0.47 \mathrm{a}$ & $24.97 \mathrm{a}$ & $1.00 \mathrm{a}$ & $1.00 \mathrm{a}$ & $1.40 \mathrm{a}$ \\
Kaolin $5.00 \%$ & $3.00 \mathrm{a}$ & $0.00 \mathrm{a}$ & $0.20 \mathrm{a}$ & $24.91 \mathrm{~b}$ & $1.53 \mathrm{a}$ & $1.00 \mathrm{a}$ & $1.32 \mathrm{a}$ \\
Kaolin $7.50 \%$ & $3.00 \mathrm{a}$ & $0.00 \mathrm{a}$ & $0.50 \mathrm{a}$ & $23.46 \mathrm{~b}$ & $1.80 \mathrm{a}$ & $1.00 \mathrm{a}$ & $1.42 \mathrm{a}$ \\
\hline
\end{tabular}

Means followed by the same letters are not significantly different at 0.05 probability using Duncan's test.

shape, leaf sunburn, berry sunburn and leaf color, while it has insignificant effect on other traits. The means comparison showed that the highest amount of bunch length was related to the use of kaolin $7.50 \%$, which did not show significant differences with other kaolin treatments, but there was a significant difference between the control and kaolin treatments. The highest bunch density was related to 5.00\% kaolin composition, which had a significant difference with control, but did not significantly differ with other concentrations of kaolin. The highest berry length was related to the application of 5.00\% kaolin, which was significantly different only with kaolin $2.50 \%$.

The highest berry width was also related to kaolin 7.50\%, which had significant differences with control but did not differ significantly with other treatments. The berry color was yellow-greenish in kaolin-treated vines, but it was yellowish in control vines and there were significant differenc- es between the control and kaolin treatments in this regard (Table 1).

The berry shape was rounded in vines treated with kaolin $7.50 \%$, which had significant differences with other treatments in this regard. The highest sunburn content of leaves and berries was related to control treatment, which was significant in comparison with kaolin treatments, but there were no significant differences between other kaolin treatments. Sunburn on berries was observed only in untreated vines and also in ones treated with $2.50 \%$ kaolin. Sunburn was not observed on berries of vines treated with kaolin treatments of $5.00 \%$ and $7.50 \%$. Sunburn on leaves was observed only in untreated vines. The best leaf color (green color) was observed in vines treated with $7.50 \%$ kaolin, which had significant differences with other treatments (Table 1).

TABLE 3. Comparison of the effect of kaolin application in mid-June and mid-July on the qualitative and quantitative characteristics of 'Thompson Seedless' grape.

\begin{tabular}{|c|c|c|c|c|c|c|c|c|}
\hline Time & $\begin{array}{l}\text { Kaolin } \\
\text { treatment }\end{array}$ & $\begin{array}{l}\text { Berry width } \\
(\mathrm{mm})\end{array}$ & $\begin{array}{l}\text { Berry length } \\
(\mathrm{mm})\end{array}$ & $\begin{array}{l}\text { Number of } \\
\text { berries }\end{array}$ & $\begin{array}{l}\text { Bunch } \\
\text { density }\end{array}$ & $\begin{array}{l}\text { Bunch weight } \\
\text { (g) }\end{array}$ & $\begin{array}{l}\text { Bunch width } \\
\qquad(\mathrm{mm})\end{array}$ & $\begin{array}{l}\text { Bunch length } \\
(\mathrm{mm})\end{array}$ \\
\hline \multirow[t]{4}{*}{ Mid-June } & $0.00 \%$ & $11.86 \mathrm{~b}$ & $13.40 \mathrm{a}$ & $132.80 \mathrm{a}$ & $3.40 \mathrm{~b}$ & $171.29 \mathrm{a}$ & $52.33 \mathrm{a}$ & $227.27 b$ \\
\hline & $2.50 \%$ & $12.10 a b$ & $13.24 \mathrm{a}$ & 137.67 a & $3.93 a b$ & $176.20 \mathrm{a}$ & $50.33 a$ & $245.20 a b$ \\
\hline & $5.00 \%$ & $12.34 \mathrm{ab}$ & $13.99 \mathrm{a}$ & $147.80 \mathrm{a}$ & $4.33 \mathrm{a}$ & $178.99 \mathrm{a}$ & $51.80 \mathrm{a}$ & $247.00 \mathrm{ab}$ \\
\hline & $7.50 \%$ & $12.48 \mathrm{a}$ & $35.59 \mathrm{a}$ & $134.93 \mathrm{a}$ & $4.20 \mathrm{a}$ & $173.41 \mathrm{a}$ & $49.62 \mathrm{a}$ & 266.93 a \\
\hline \multirow[t]{4}{*}{ Mid-July } & $0.00 \%$ & $12.29 \mathrm{ab}$ & $13.42 \mathrm{a}$ & $132.93 \mathrm{a}$ & $3.93 a b$ & $161.52 \mathrm{a}$ & $52.66 \mathrm{a}$ & $253.13 a b$ \\
\hline & $2.50 \%$ & $12.18 \mathrm{ab}$ & $13.45 \mathrm{a}$ & 159.87 a & $4.47 \mathrm{a}$ & $199.95 \mathrm{a}$ & $58.55 a$ & $260.20 \mathrm{a}$ \\
\hline & $5.00 \%$ & $12.03 a b$ & $13.32 \mathrm{a}$ & $140.80 \mathrm{a}$ & $4.20 \mathrm{a}$ & $182.72 \mathrm{a}$ & $55.58 \mathrm{a}$ & $246.93 a b$ \\
\hline & $7.50 \%$ & $12.51 \mathrm{a}$ & $13.51 \mathrm{a}$ & $163.33 \mathrm{a}$ & $4.47 \mathrm{a}$ & 220.94 a & $50.92 \mathrm{a}$ & 265.67 a \\
\hline Time & $\begin{array}{c}\text { Kaolin } \\
\text { treatment }\end{array}$ & $\begin{array}{l}\text { Leaf } \\
\text { color }\end{array}$ & $\begin{array}{c}\text { Leaf } \\
\text { sunburn }\end{array}$ & $\begin{array}{c}\text { Berry } \\
\text { sunburn }\end{array}$ & $\begin{array}{l}\text { TSS } \\
(\%)\end{array}$ & $\begin{array}{l}\text { Berry } \\
\text { color }\end{array}$ & $\begin{array}{l}\text { Berry } \\
\text { shape }\end{array}$ & $\begin{array}{l}\text { Berry weight } \\
\text { (g) }\end{array}$ \\
\hline \multirow[t]{4}{*}{ Mid-June } & $0.00 \%$ & $1.00 \mathrm{c}$ & $2.33 b$ & $2.33 \mathrm{c}$ & $23.54 \mathrm{c}$ & $1.53 \mathrm{~d} c$ & $1.80 \mathrm{~b}$ & $1.30 \mathrm{a}$ \\
\hline & $2.50 \%$ & $3.00 \mathrm{~b}$ & $0.00 \mathrm{a}$ & $0.067 \mathrm{a}$ & $24.93 a b$ & $1.80 \mathrm{bc}$ & $1.00 \mathrm{c}$ & $1.40 \mathrm{a}$ \\
\hline & $5.00 \%$ & $3.00 \mathrm{~b}$ & $0.00 \mathrm{a}$ & $0.00 \mathrm{a}$ & $23.73 \mathrm{c}$ & $2.73 \mathrm{a}$ & $2.60 \mathrm{a}$ & $1.45 \mathrm{a}$ \\
\hline & $7.50 \%$ & $4.33 \mathrm{a}$ & $0.00 \mathrm{a}$ & $0.00 \mathrm{a}$ & $23.53 c$ & $2.33 \mathrm{ab}$ & $1.13 c$ & $1.41 \mathrm{a}$ \\
\hline \multirow[t]{4}{*}{ Mid-July } & $0.00 \%$ & $1.00 \mathrm{C}$ & $3.00 \mathrm{c}$ & $1.33 b$ & $25.41 \mathrm{a}$ & $1.40 \mathrm{dc}$ & $1.27 \mathrm{c}$ & $1.39 a$ \\
\hline & $2.50 \%$ & $3.00 \mathrm{~b}$ & $0.00 \mathrm{a}$ & $0.47 a$ & $24.97 \mathrm{ab}$ & $1.00 \mathrm{~d}$ & $1.00 \mathrm{c}$ & $1.40 \mathrm{a}$ \\
\hline & $5.00 \%$ & $3.00 \mathrm{~b}$ & $0.00 a$ & $0.20 \mathrm{a}$ & $23.46 \mathrm{c}$ & $1.53 \mathrm{dc}$ & $1.00 \mathrm{c}$ & $1.32 \mathrm{a}$ \\
\hline & $7.50 \%$ & $3.00 \mathrm{~b}$ & $0.00 \mathrm{a}$ & $0.60 \mathrm{a}$ & $23.91 \mathrm{bc}$ & $1.80 \mathrm{bc}$ & $1.00 \mathrm{c}$ & $1.42 \mathrm{a}$ \\
\hline
\end{tabular}

Means followed by the same letters are not significantly different at 0.05 probability using Duncan's test. 

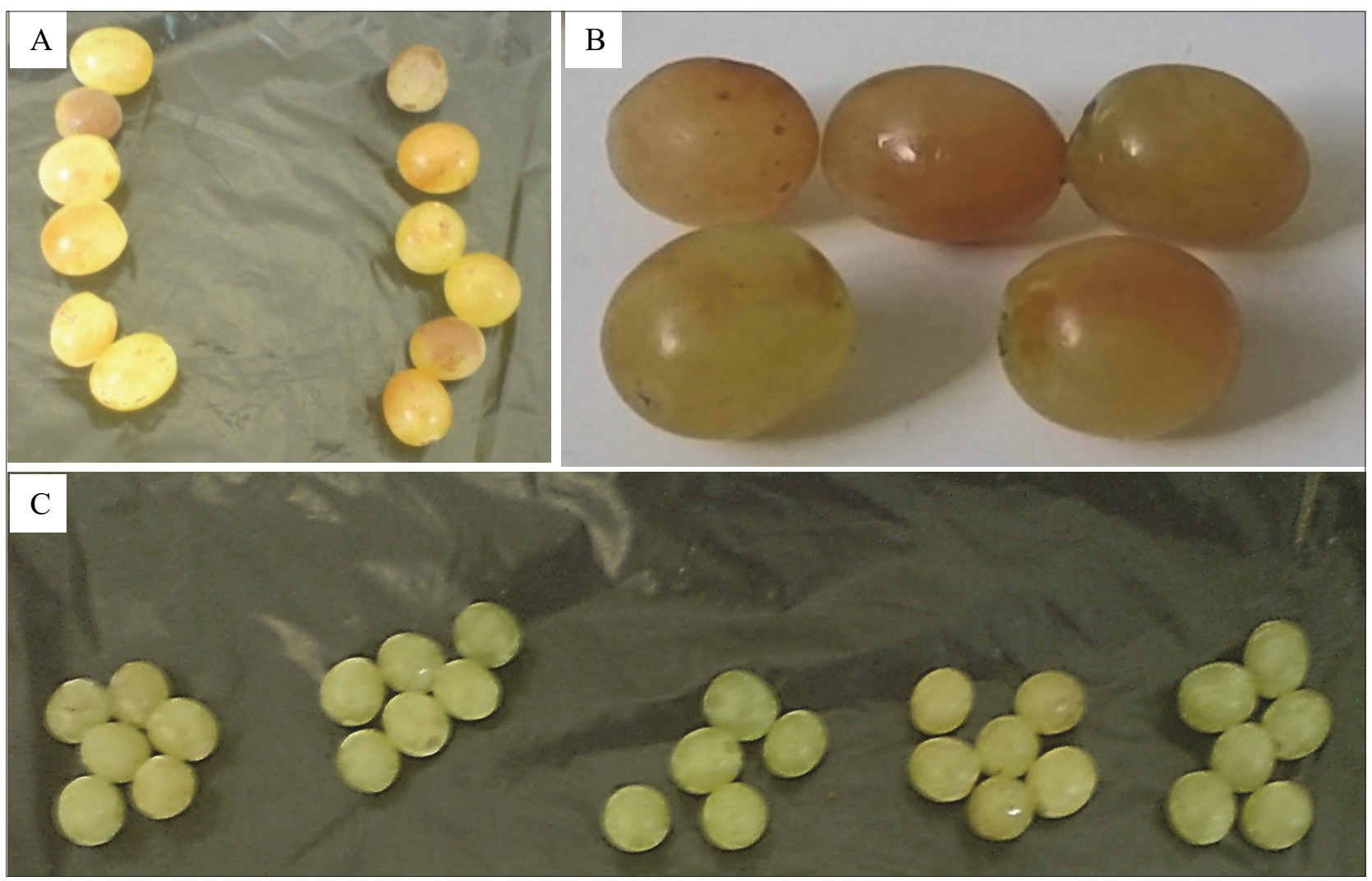

FIGURE 1. The effect of kaolin application on sunburn damage in 'Thompson Seedless' grape berries. A) and B) Untreated berries: the presence of sunburn; C) Treated berries: no sunburn.

\section{Kaolin application in mid-July}

The analysis of variance showed that the application of kaolin in mid-July had significant effects on bunch weight, TSS, leaf sunburn and leaf color. The highest bunch weight was observed in the vines treated with $7.50 \%$ kaolin, which had no significant differences with other kaolin treatments, but it was significantly different compared with control. The highest TSS was related to control treatment, which did not show a significant difference with $2.50 \%$ kaolin treatment, but it was significantly different compared with $5.00 \%$ and $7.50 \%$ of kaolin treatments.

The highest sunburn on berries and leaves was observed in untreated vines. Kaolin treatments $(2.50,5.00$, and $7.50 \%)$ did not significantly differ in this regard with each other, but they had significant differences with control. There were no significant differences between different treatments of kaolin $(2.50,5.00$, and $7.50 \%)$ in terms of leaf color quality, but they had higher qualities than the control (Table 2).

\section{The comparison between kaolin application times}

The comparison of kaolin application in mid-June and mid-July showed that the traits including berry shape, TSS, leaf color, berry sunburn, and leaf sunburn were significantly affected. The highest bunch length was related to the application of kaolin $7.50 \%$ in mid-June. The bunch density in vines treated with 2.50 and $7.50 \%$ kaolin was higher than other treatments. The highest value of berry width was related to the treatment of $7.50 \%$ kaolin in mid-July. The highest value of TSS was obtained from control in mid-July. The berry color in the control vines was yellowish in both times, while it was greenish in vines treated with kaolin in mid-June and mid-July. The berry shape was more stretched in vines treated with $5.00 \%$ kaolin in mid-June (Table 3).
The highest sunburn on the berries was related to untreated vines in mid-June (Figure 1A) and after that, in untreated vines in mid-July (Figure 1B). The lowest amount of sunburn on berries was related to the treatment of $5.00 \%$ and $7.50 \%$ kaolin in mid-June, and all the vines treated with kaolin had lower amount of sunburn on berries than control at both times (Figure 1C).

Sunburn on leaves was observed only in control vines and none of the vines treated with kaolin had sunburn on leaves. The best leaf coloration (darker green color) was observed in the vines treated with $7.50 \%$ kaolin in mid-June and there were significant differences between kaolin treatments in mid-June and mid-July with the control (Table 3).

\section{Discussion}

It seems that the interaction of temperature and light causes sunburn disorder in fruit and leaf (Schrader et al., 2009). By creating a protective layer around the fruit while retaining its moisture, kaolin reduces the negative effects of intense sunlight that causes sunburn (Glenn et al., 2002). It is reported that kaolin, by reflecting ultraviolet and infrared wavelengths, prevents heat from the plant and prevents sunburn of the product (Schrader et al., 2009).

The results of the present study showed that the highest amount of berry sunburn was observed in untreated vines and the lowest amount of berry sunburn was observed in the treated vines with kaolin in mid-June, and leaf sunburn in all the kaolin treatments was not observed at both times, while untreated vine had high sunburn in leaves.

Glenn et al. (2002) observed a decrease in the fruit sunburn content of apple by application of kaolin in concentrations of 3.00, 6.00 and $12.00 \%$. Melgarjo et al. (2003) with kaolin spraying on a pomegranate tree (Punica granatum) 
from late June to mid-July, reported that white coating produced by kaolin significantly reduced the damage of fruit sunburn.

The results of the current experiment also showed a positive effect of kaolin on traits such as bunch length, bunch density and berry width. There was a significant difference in the bunch length, berry width, and bunch density of the vines treated with kaolin $7.50 \%$ compared with controls. It seems that kaolin has increased fruit size by decreasing water evaporation from the fruit surface (Wand et al., 2006). This combination may have a positive effect on fruit size in other methods including the effect on the hormonal content of fruit. It is likely that due to the shadow created by kaolin, there has been less auxin loss in the fruit, and in this way, more growth has taken place, which requires further investigation to confirm (Yakushiji and Hase, 1991).

In the present experiment, the effect of kaolin on the berry color was significant and the treated vines had a greenish color compared with the control. Wand et al. (2006) reported the effect of kaolin on reducing the level of fruit coloration. The production of anthocyanin and its accumulation in plant tissues is influenced by various factors such as the quality of light and its intensity, as well as the value of carbohydrates in tissues (Taiz and Zeiger, 2006). In addition, Glenn and Puterka (2001) argued that kaolin increased the reflection of radiation reaching the leaf sunburn, thereby reducing the heat load of the tree and increasing its fertility. The positive effect of kaolin has been reported to increase the amount of photosynthesis in the grape-fruit (Jifon and Syvertsen, 2001).

\section{Conclusions}

Kaolin application was effective for preventing the sunburn occurrence and improving berry quality in the studied grape. The kaolin significantly reduced the severity of sunburn damage on grape leaves and berries. The results showed that the sunburn on the berries and leaves was lower in the treated trees than in untreated trees, and the best result was achieved with kaolin used in mid-June, which could completely control leaf sunburn. The result also showed that kaolin had a positive effect on bunch length, bunch weight, bunch density, berry length and berry width. Therefore, it is suggested that foliar application of kaolin is a suitable, affordable and inexpensive solution to reduce the damages caused by sunburn in leaves and fruits, especially in areas where the intensity of the sun is high.

Kaolin is cheap and easy to use and requires less care than other methods when it is consumed. However, the removal of kaolin residues during fruit harvest may require washing and flushing of fruits (Schupp et al., 2002). Recently, a system has been invented in South Africa, which largely eliminates the remains of this material, but this system is still in the test phase. Fruit washing at the post-harvest stage, which is used to remove insects, dust, and other sticky substances, can significantly reduce the depletion of kaolin from the fruit surface (Wünsche et al., 2004). Due to the fact that there were no sunburns in the vines treated with kaolin in mid-June, it is recommended that this solution may be used in mid-June.

\section{Acknowledgments}

The present data belongs to the M.Sc. thesis of the first author and we would like to thank Arak University in Iran for its financial support (grant number: 95/10124).

\section{References}

Attra. (2002). Considerations in organic apple production. http:// www.attra.org/attrapub/PDF/kaolin-clay-apples.pdf.

FAO (2014). Faostat Statistical Database. www.FAO.com.

Glenn, D.M. (2005). Particle films: A new technology for agriculture. Hortic. Rev. 31, 1-44.

Glenn, D.M., and Puterka, G.J. (2001). Particle film application influences apple leaf physiology, fruit yield, and fruit quality. J. Am. Soc. Hortic. Sci. 126(2), 175-181. https://doi.org/10.21273/ JASHS.126.2.175.

Glenn, D.M., Puterka, G.J., vanderZwet, T., Byers, R.E., and Feldhake, C. (1999). Hydrophobic particle films: A new paradigm for suppression of arthropod pests and plant diseases. J. Econ. Entomol. 92, 759-771. https://doi.org/10.1093/jee/92.4.759.

Glenn, D.M., Prado, E., Erez, A., McFerson, J., and Puterka, G.J. (2002). A reflective, processed-kaolin particle film affects fruit temperature, radiation reflection, and solar injury in apple. J. Am. Soc. Hortic. Sci. 127, 188-193. https://doi.org/10.21273/JASHS.127.2.188.

Glenn, D.M., Erez, A., Puterka, G.J., and Gundrum, P. (2003). Particle films affect carbon assimilation and yield in 'Empire' apple. J. Am. Soc. Hortic. Sci. 128, 356-362. https://doi.org/10.21273/ JASHS.128.3.0356.

Jifon, J.L., and Syvertsen, J.P. (2001). Effects of moderate shade on citrus leaf gas exchange, fruit yield and quality. Proc. Florida State Hortic. Soc. 114, 177-181.

Keller, M. (2010). The science of grapevine. Anatomy and Physiology (Elsevier).

Melgarejo, P., Martinez, J.J., Hernandez, F., Martinez-Font, R., Barrows, P., and Erez, A. (2003). Kaolin treatment to reduce pomegranate sunburn. Sci. Hortic. 100, 349-353. https://doi.org/10.1016/j. scienta.2003.09.006.

Saleh, M.S., and EL-Ashry, S.M. (2006). Effect of some antitranspirants on leaf mineral content, fruitset, yield and fruit quality of Washington Navel and Succary orange trees. J. Appl. Sci. Res. 2(8), 486-490.

Saour, G. (2005). Morphological assessment of olive seedling treated with kaolin-based particle film and bistimulant. Adv. Hortic. Sci. 20(1), 1-5.

Saour, G., and Makee, H. (2003). Effects of kaolin particle film on olive fruit yield, oil content and quality. Adv. Hortic. Sci. 17(4), 204-206.

Schrader, L.E., Kahn, C., and Elfving, D.C. (2009). Sunburn browning decreases at-harvest internal fruit quality of apples (Malus domestica Borkh.). Int. J. Fruit Sci. 9, 425-437. https://doi. org/10.1080/15538360903378781.

Schupp, J.R., Fallahi, E., and Chun, J.-J. (2002). Effect of particle film on fruit sunburn maturity and quality of 'Fuji' and 'Honeycrisp' apple. HortTechnology 12(1), 87-90. https://doi.org/10.21273/ HORTTECH.12.1.87.

Taiz, L., and Zeiger, E. (2006). Plant Physiology, $4^{\text {th }}$ ed. (Sunderland, Mass.: Sinauer Associates), 623 pp.

This, P., Lacombe, T., and Thomas, M.R. (2006). Historical origins and genetic diversity of wine grapes. Trends Genet. 22, 511-519. https:// doi.org/10.1016/j.tig.2006.07.008.

Wand, S.J.E., Theron, K.I., Ackerman, J., and Marais, S.J.S. (2006). Harvest and post-harvest apple fruit quality following applications of kaolin particle film in South African orchards. Sci. Hortic. 107, 271-276. https://doi.org/10.1016/j.scienta.2005.11.002.

Wünsche, J.N., Lombardini, L., and Greer, D.H. (2004). 'Surround' particle film applications-effects on whole canopy physiology of apple. Horticulture 636, 565-571. https://doi.org/10.17660/ ActaHortic.2004.636.72. 
Yakushiji, H., and Hase, Y. (1991). Influence of number of seeds and tree shading on June drop phytohormone content of Japanese persimmon (Diospyros kaki) Fuyu fruit. Bull. Fruit Tree Res. Station 19, 49-59.

Zhang, J., Ma, H., Chen, S., Ji, M., Perl, A., Kovac, L., and Chen, C. (2009). Stress response protein's differential expression in embryogenic and non-embryogenic callus of Vitis vinifera L. cv. Cabernet Sauvignon - A proteomic approach. Plant Sci. 177, 103-113. https://doi. org/10.1016/j.plantsci.2009.04.003.

Received: Nov. 11, 2017

Accepted: Jul. 4, 2018

Addresses of authors:

Abolfazl Hosseinabad and Ali Khadivi*

Department of Horticultural Sciences, Faculty of Agriculture and Natural Resources, Arak University, 38156-8-8349 Arak, Iran

* Corresponding author;

E-mail: a-khadivi@araku.ac.ir;

Tel./Fax: +98-86-32762087 